\title{
Socio-economic Impacts-Recreation
}

\author{
Edgar Kreilkamp, Nele Marisa von Bergner and Claudia Mauser
}

\begin{abstract}
Tourism is one of the most highly climate-sensitive economic sectors. Most of its main sub-sectors, including sun-and-beach tourism and nature-based tourism, play a major role in the North Sea region and are especially weather-und climate-dependent. On top of that, most tourist activities in the North Sea region occur in the coastal zones which are highly vulnerable to the impacts of climate change. Climate acts as both a 'push' and 'pull' factor in tourism. Climate-driven changes in tourism demand are hard to determine because the tourist decision-making process is also influenced by factors other than climate. Nevertheless, summer tourism in the North Sea region is expected to benefit from rising temperatures (air and water), decreasing precipitation and longer seasons. Destinations can reduce the negative impacts of climate change on tourism by adapting to the changes. The tourist industry also contributes to climate change. Not only is the tourist industry affected by climate change, it also contributes to climate change itself. Therefore, mitigating the climate effects of tourism is largely the responsibility of politicians, the tourism industry and tourism supply. Despite some negative impacts, the overall consequences of climate change for tourism in the North Sea region are expected to be positive.
\end{abstract}

\subsection{Introduction}

The United Nations World Tourism Organization states that tourism is one of the most highly climate-sensitive (and even in some cases climate-dependent) economic sectors. Climate change is therefore a major challenge for global tourism (UNWTO 2009; von Bergner and Lohmann 2014). The main sub-sectors include sun-and-beach tourism, sports tourism, adventure tourism, nature-based tourism, cultural

E. Kreilkamp $(\bowtie)$

Institute of Corporate Development, Leuphana University

of Lüneburg, Lüneburg, Germany

e-mail: edgar.kreilkamp@uni.leuphana.de

N.M. von Bergner

Institute for Tourism and Leisure ITF, HTW Chur,

Chur, Switzerland

e-mail: nelemarisa.vonbergner@htwchur.ch

C. Mauser

IFOK GmbH, Bensheim, Germany

e-mail: claudiamauser@gmx.de tourism, urban tourism, health and wellness tourism, cruises, theme parks, visiting friends and relatives, and meetings and conferences (Scott and Lemieux 2010). Most of these are weather- and climate-dependent and play a major role in the North Sea region.

\subsection{Literature Review}

The complex relationship between climate change and tourism has been part of the academic debate since the $1980 \mathrm{~s}$ (Fig. 17.1). The first papers concerning climate change and tourism were published in 1986 (Harrison et al. 1986; Wall et al. 1986). Since then, the number of publications in this field has increased steadily (Fig. 17.2) up to 83 publications in 2011. From a review of literature between 1986 and 2012, Becken (2013) concluded that half of the studies concerned climate impacts on tourism, $34 \%$ dealt with mitigation, and the remaining $16 \%$ were policy papers or integrative papers. 


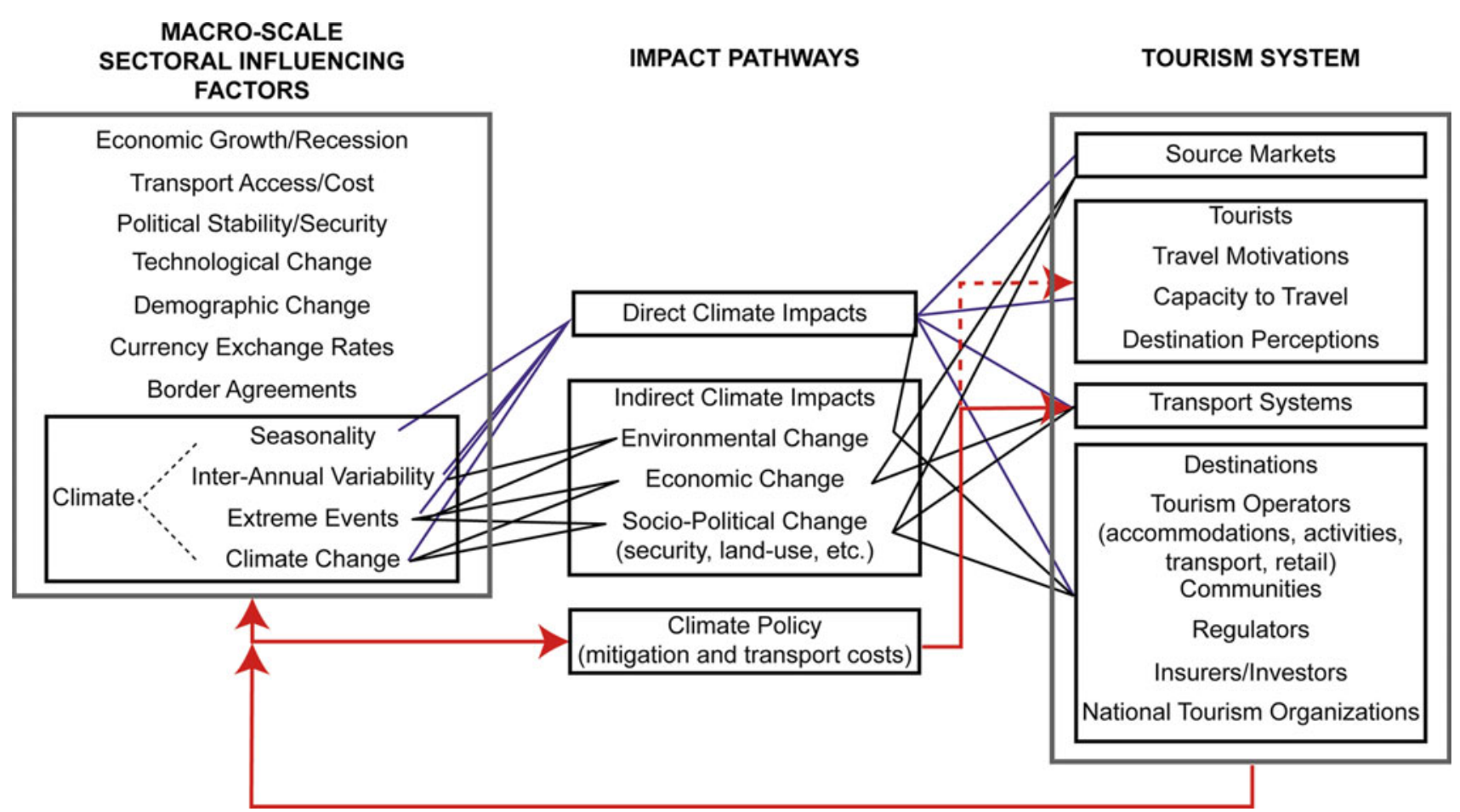

Fig. 17.1 Relationship between climate change and tourism (Scott and Lemieux 2010)

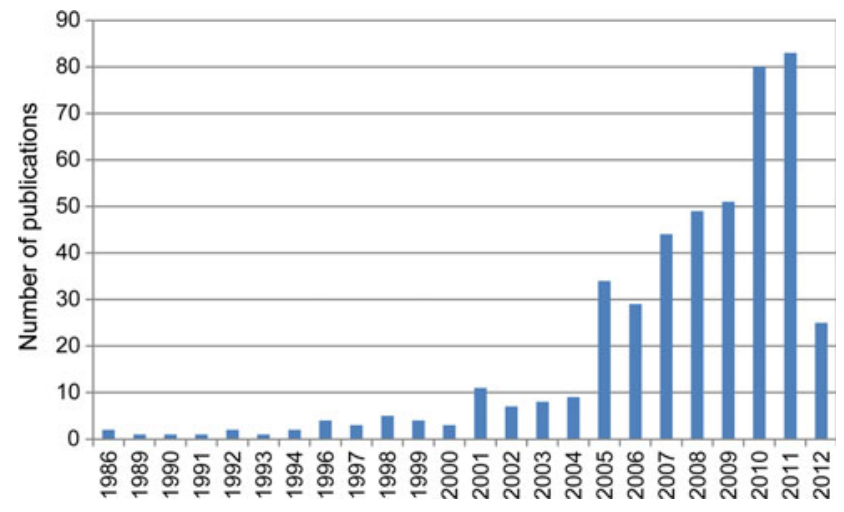

Fig. 17.2 Number of peer-reviewed publications concerning climate change and tourism produced per year between 1986 and 2012 (Becken 2013)

Although climate is not the only determinant of destination choice (Crouch 1995; Witt and Witt 1995; Rosselló et al. 2005; Gössling and Hall 2006; Bigano et al. 2006a), attractiveness is largely determined by thermal environmental assets (Smith 1993; Agnew and Palutikof 2000; Amelung and Viner 2006; for a detailed literature overview on how climate/weather and tourism interact, see Becken 2010). Destinations with better climate resources have a competitive advantage (Perch-Nielsen et al. 2010), especially those for sun-and-sea or winter sports holidays. In tourism, climate acts as both a 'push' and 'pull' factor. A push factor is one where the choice of travel destination is often related to the weather and climate conditions at the point of origin and not just at the holiday region. For example, Hill (2009) found that very rainy weather throughout much of the early summer in the United Kingdom resulted in an increase in foreign holiday bookings abroad compared to the previous year. But climate may also act as a pull factor. In Norway, $84 \%$ of tour operators go to 'sun destinations' (Jorgensen and Solvoll 1996). This is not a recent phenomenon. Even in 1999, an annual survey of German traveller behaviour and tourism-related attitudes showed that $43 \%$ of Germans mentioned weather as the most important factor when choosing a holiday destination (Lohmann and Kaim 1999). Nevertheless, preferences or perceptions of climate differ according to several factors, such as age, cultural and climate contexts, as well as leisure activities or the media, and are therefore hard to predict (Lise and Tol 2002; overview of literature by Gössling et al. 2012, Scott et al. 2012a).

One means of quantifying these preferences is through a 'climate index'; the aim being to provide a measure of the integrated effects of the atmospheric environment on a particular location. This would be useful both for tourists and for the tourism industry to evaluate the potential of tourism in a given area in terms of its perceived climate (de Freitas et al. 2008). The index approach can also be used to analyse the impact of climate change on the climatic attractiveness of tourist destinations (Hamilton 2005). One of the most used indices is that of Mieczkowski (1985), who developed the 
Table 17.1 Priority levels for climate aspects (Morgan et al. 2000)

\begin{tabular}{l|l}
\hline Climate aspect & $\begin{array}{l}\text { Relative priority scores (out of } 100 \\
\text { for aspects 1-4) }\end{array}$ \\
\hline Windiness & 26 \\
\hline Absence of rain & 29 \\
\hline Sunshine & 27 \\
\hline Temperature sensation & 18 \\
\hline $\begin{array}{l}\text { Bathing water temperature } \\
\left(22-26^{\circ} \mathrm{C}\right)\end{array}$ & $(28)$ \\
\hline
\end{tabular}

Tourism Climate Index (TCI). This integrates several climate features into a single index and includes ratings for thermal comfort, physical features (e.g. rain) and aesthetic features (e.g. sunshine duration). Although Mieczkowski's index has been criticised by de Freitas (2003) owing to its subjectivity, it is still being used or adapted by others (Scott and McBoyle 2001; Scott et al. 2004; Amelung and Viner 2006; Amelung et al. 2007; Nicholls and Amelung 2008). Morgan et al. (2000) modified the index to fit beach users in the UK, using five aspects of climate (Table 17.1).

Matzarakis (2007) used the index to develop a Climate Tourism Information Scheme (CTIS) that includes parameters such as cold stress, heat stress and snow fall (i.e. skiing potential). This approach was also used for regional simulations of future conditions along the German North Sea coast (based on two regional climate models-REMO and CLM) that takes into account local-scale differences between the mainland coast and islands (Endler and Matzarakis 2010).

This chapter reviews information on climate change and its impact on recreation and tourism in the North Sea region. Because this is concentrated along the coast, the focus of this chapter is on the impacts of climate change on coastal tourism.

\subsection{Impacts of Climate Change}

Coastal tourism is the largest component of the tourism industry worldwide (IPCC 2014a). At the same time, coastal zones are especially vulnerable to the impacts of climate change. Even so, until 2012 few studies had addressed the topic of coastal tourism and climate change (Becken 2013). Despite some studies for the Caribbean or Mediterranean Sea and a few other beach or island regions (Nicholls and Hoozemans 1996; Lohmann 2002; Giupponi and Shechter 2003; Nicholls and Klein 2003; Perry 2005, 2006; Amelung and Viner 2006; Hein 2007; Giannakopoulos et al. 2009; Lemelin et al. 2010; Perch-Nielsen 2010; Becken et al. 2011; Jones and Phillips 2011; Scott et al. 2012c) there has been very little published on climate change impacts on tourism in the North Sea region. Those studies that do exist are all discussed in this chapter. Figure 17.2 shows the recent increase in publications on the impact of climate change on coastal tourism. Some of these studies address the response of tourists and tour operators to beach erosion and the tourist's concern about aesthetic appearance (Moreno and Becken 2009; Buzinde et al. 2010), while others examine the vulnerability of coastal tourism infrastructure to sea-level rise (Phillips and Jones 2006; Bigano et al. 2008; Schleupner 2008).

Negative effects of climate change include rising sea levels and extreme weather. Extreme storms and waves together with sea-level rise will increase the extent and frequency of flooding, storm surges and coastal erosion. Not only will this affect natural areas used by tourists, but also cultural assets and tourism infrastructure, especially transportation and accommodation (Phillips and Jones 2006; Amelung and Viner 2007; Scott et al. 2008). From a study of beach tourism in East Anglia, Coombers et al. (2009) showed that although sea-level rise would reduce the width of the beach and cause a possible reduction in visitor numbers, this effect could be outweighed by increased visitation due to better temperatures. However, overall, the economic costs of negative climate change impacts on coastal tourism could become extremely high (IPCC 2014a).

Positive effects of climate change on tourism have also been predicted. The North Sea coastal region has a maritime climate, which means mild winters and relatively warm summers. Climate projections suggest fewer cold stress events in winter, and less significant changes in heat stress events in summer compared to other regions such as the Mediterranean. The higher average temperatures projected by climate models imply a positive effect on the well-being of tourists in the North Sea region. For example, higher temperatures in summer may result in a longer (bathing) season (Pinnegar et al. 2006; Nicholls and Amelung 2008). Changes in precipitation patterns are expected to result in dryer summers and wetter winters. A decrease in summer precipitation may attract more tourists to the North Sea coastal areas. More rain and extreme weather events in winter could reduce the number of visitors in the low season.

Sea-level rise will become a major threat in the North Sea region (see Chap. 6), especially for low-altitude islands with limited tidal range, and coastal areas are particularly vulnerable to extreme weather events (Moreno and Becken 2009). Storm-surge height and the frequency of extreme wave events are expected to increase over large areasespecially in winter (IPCC 2014a). The IPCC cites an increase in future flood losses along the North Sea coast (IPCC 2014b), which may also affect the tourism industry. Even though tourist destinations recover relatively quickly from such disasters, damage to infrastructure and buildings will result in additional costs. Adaptation to climate change will also have economic impacts: Hamilton (2006) showed that protection measures such as longer dikes have a 
negative impact on accommodation prices along the German sea coast.

Braun et al. (1999) investigated combined scenarios of temperature and precipitation change with sea-level rise and beach loss and their effect on the number of tourists travelling to the Baltic and North Sea coasts of Germany. They concluded that the likelihood of choosing the north German coast for a holiday was slightly higher with increased temperatures. However, for scenarios with potentially negative impacts on the German coasts, such as beach erosion, the likelihood of visiting was substantially lower, even if with adaptations such as greater setback of tourism infrastructure or more diversified outdoor activities. Lohmann (2002) concluded that the effects of climate change in the North Sea area, such as sea-level rise, were likely to destroy infrastructure and that frequent extreme weather events may discourage visitors.

Infrastructure at ports and marinas is a major asset at many destinations. Sea-level rise, coastal erosion and storms might compromise its functionality. There is still a lack of detailed academic research on this topic for the North Sea region.

For the German North Sea coastline, sea-level rise is expected to extend the tides (i.e. lengthen flood duration on mudflats) hampering tidal flat walks for tourists (Regierungskommission Klimaschutz 2012).

Higher average temperatures in the North Sea region will also cause tourism-driven changes in biodiversity. If more tourists visit the North Sea in, before and after the summer season, this might increase pressure on local biodiversity, in particular vegetation cover and habitat for nesting birds (Coombers et al. 2008). Effects on nature-based tourism and activities, like animal watching, still require closer academic study. Travellers to the Baltic Sea coast judged algal blooms negatively, especially for swimming (Nilsson and Gössling 2012). There is also concern that foam algae might pollute the beaches (Regierungskommission Klimaschutz 2012). Further studies are needed to examine the (potentially toxic) effects of new plant species moving into the North Sea region and an increase in harmful algal blooms could impact on bathing water quality and the tourism industry in general over the longer term (Gössling et al. 2012). Broader socio-economic impacts of climate change on destinations, such as those concerning health, security or insurance implications should also be considered. Heat waves in summer might adversely affect health resorts, but it may be that such conditions are still preferable to those of other inland destinations and will therefore have an advantage in the future. Knowledge gaps still remain on health issues, especially the future distribution of vector-borne disease along the North Sea coast.

Overall, tourism in the North Sea area in summer is expected to profit from rising temperatures (air and water), decreasing precipitation and a longer season. But climate-driven changes in tourism demand are hard to determine because the tourist decision-making process is influenced by many other factors in addition to climate (IPCC 2014a). In addition to the direct impacts of climate change on tourism and its infrastructure, the more complex and indirect effects of climate change are also important because climate change affects all economic sectors, politics and society as a whole (Kreilkamp 2011).

\subsection{Changing Patterns in Tourism Flow}

Climate change may also alter tourism patterns in Europe radically by inducing changes in destination choice and seasonal demand structure (Ciscar et al. 2011: 2680). The scientific literature contains many references to tourists, their preferences and their behaviour, including changes in tourist flows and seasonality (Braun et al. 1999; Maddison 2001; Lise and Tol 2002; Wietze and Tol 2002; Lohmann 2003; Hamilton et al. 2005; Gössling and Hall 2006; Bigano et al. 2006b, 2008; Hamilton and Tol 2007; Moreno and Amelung 2009; Buzinde et al. 2010; Hall 2010; Perch-Nielsen et al. 2010; Denstadli et al. 2011; Rosselló-Nadal et al. 2011; Gössling et al. 2012). One of the major questions these studies raise is whether mass tourism of the type seen today at the Mediterranean Sea coast will shift to destinations in northern Europe, such as the North Sea region. Climate change could also result in a seasonal change in visits.

The climate for tourist activities in the North Sea is expected to improve significantly in summer but less so in autumn and spring for northern continental Europe, Finland, southern Scandinavia, and southern England, especially after 2070 (Amelung et al. 2007; Nicholls and Amelung 2008; Amelung and Moreno 2012). At the same time, the attractiveness of the Mediterranean Sea region is expected to decline as comfort distribution changes from a 'summer peak' to a 'bimodal distribution', with less attractive summers and more attractive springs and autumns (Amelung and Viner 2006; Amelung et al. 2007; Moreno and Amelung 2009; Hein 2009; Perch-Nielsen et al. 2010; Moriondo et al. 2011), see also Table 17.2.

However, studies conclude that by 2030 (or even 2060) the Mediterranean Sea region will not have become too hot for beach tourism (Moreno and Amelung 2009; Rutty and Scott 2010), because surveys show that it is mostly rain that drives beach tourists away (de Freitas et al. 2008; Moreno 2010). Domestic tourism and international visits from southern Europe to locations in northern Europe may increase at the expense of southern locations (Hamilton and Tol 2007; Willms 2007; Hein 2009; Amelung and Moreno 2012; Bujosa and Rosselló 2012). The Intergovernmental Panel on Climate Change stated with medium confidence that tourism activity may increase in northern and 
Table 17.2 Qualitative assessment of the impact of climate change (IPCC SRES A1F scenario) on sustainable tourism development in the Balearic Islands in the 21st century (Amelung and Viner 2006)

\begin{tabular}{|c|c|c|c|c|c|}
\hline & Spring & Summer & Autumn & Winter & Net effect \\
\hline Revenue & $\uparrow \uparrow$ & $\downarrow \downarrow \downarrow$ & $\downarrow \downarrow$ & $\uparrow \uparrow$ & $\downarrow \downarrow$ \\
\hline Occupancy & $\uparrow \uparrow$ & $\downarrow \downarrow$ & $\leftrightarrow / \downarrow$ & $\uparrow \uparrow$ & $\uparrow$ \\
\hline Employment & $\uparrow \uparrow$ & $\downarrow \downarrow \downarrow$ & $\downarrow \downarrow$ & $\uparrow \uparrow$ & $\downarrow \downarrow$ \\
\hline Migration & $\uparrow$ & $\downarrow \downarrow \downarrow$ & $\downarrow \downarrow$ & $\leftrightarrow$ & $\downarrow \downarrow$ \\
\hline Water use & $\uparrow \uparrow$ & $\downarrow \downarrow \downarrow$ & $\downarrow \downarrow$ & $\uparrow \uparrow$ & $\downarrow$ \\
\hline Impact on biodiversity & $\uparrow \uparrow \uparrow$ & $\downarrow \downarrow \downarrow$ & $\downarrow \downarrow$ & $\uparrow$ & $\downarrow$ \\
\hline
\end{tabular}

continental Europe, developing travelling patterns closer to home (IPCC 2014b). Nevertheless, no significant changes in the tourism sector are expected before 2050.

A spatial and temporal redistribution of tourism through climate change could lead to shifts, such as Europeans extending their tourism activities over a longer period, taking trips to the Mediterranean Sea region in spring and autumn, and to northern Europe in summer (Ciscar et al. 2011). However, a key assumption is that the tourism system has full flexibility in responding to climate change (Ciscar et al. 2011: 2681). Studies are also needed to address any new environmental challenges appearing along the North Sea coast, for example if more infrastructure and buildings are needed for the already well visited summer period.

However, there are limitations to those forecasts. Preferred beach temperatures differ among travellers from different countries (Scott et al. 2008; Rutty and Scott 2010). According to Maddison (2001), British tourists are attracted to climates around an average of $30.7{ }^{\circ} \mathrm{C}$, which they are unlikely to find in northern Europe even with climate change. Rutty and Scott (2013) interviewed beach tourists on Caribbean islands and found that travellers from the UK preferred temperatures of $27-30{ }^{\circ} \mathrm{C}$ while Germans preferred $30^{\circ} \mathrm{C}$. It was shown that preferred beach temperatures differ among travellers from different countries (Scott et al. 2008; Rutty and Scott 2010). Rutty and Scott (2010) also found that the impact of media news about heat waves on travel decisions varied according to the level of commitment to the trip (planning a holiday or a trip already booked). Hall (2012) listed the major weaknesses of current models in predicting travel flow as follows: validity and structure of statistical databases; temperature assumed to be the most important weather parameter; role of information in decision-making unclear; role of non-climatic parameters unclear (e.g. social unrest, political instability, risk perceptions, destination perception); assumed linearity of change in behaviour unrealistic; and future costs of transport and availability of tourism infrastructure uncertain.

The assumption that rising temperatures will be positive for northern European tourist destinations does not consider the impact of other, potentially negative environmental changes in the region (e.g. Hall 2008). Also, there are tourists that still want to travel to regions where they expect resources other than the weather. For example, Moreno (2010) found that almost three-quarters of visitors from Belgium and the Netherlands questioned would still travel to the Mediterranean Sea region even if their self-defined preferred climatic conditions existed in northern Europe. For some people, certain destinations appeal for reasons largely unaffected by climate change, including uniqueness, travel time, standard and cost of accommodation, perceived safety and security, existing facilities, services, access, and host hospitality (Hall 2005). It becomes clear that climate change is just one out of many factors affecting their attractiveness.

\subsection{Mitigation and Adaptation Policies}

Destinations can seek to lessen the impact of climate change on tourism by adapting to the changes (Gössling et al. 2012). Several studies address both adaptation and mitigation (see Scott and Becken 2010; Scott et al. 2012b; Becken 2013 and Gössling et al. 2013).

As tourists are flexible in their destination choice and because tourism operators can easily change their portfolio, adaptation measures are of special importance for tourism suppliers on site. The choice of adaptation measures (for example when securing infrastructure, rebuilding accommodation, and changing transport) will depend on the type and magnitude of the climate impacts. They may also affect destination attractiveness. For example, raising seawalls on the North Sea coast could result in a less appealing landscape (Regierungskommission Klimaschutz 2012). More research is needed to understand the role of coastal zone management and tourism activities in climate change adaptation, especially in the North Sea region.

In deciding on long-lasting adaptation measures and investigations, the tourism sector faces two fundamental issues: uncertainty in climate scenarios (Turton et al. 2010) and short investment cycles (Bicknell and McManus 2006). 

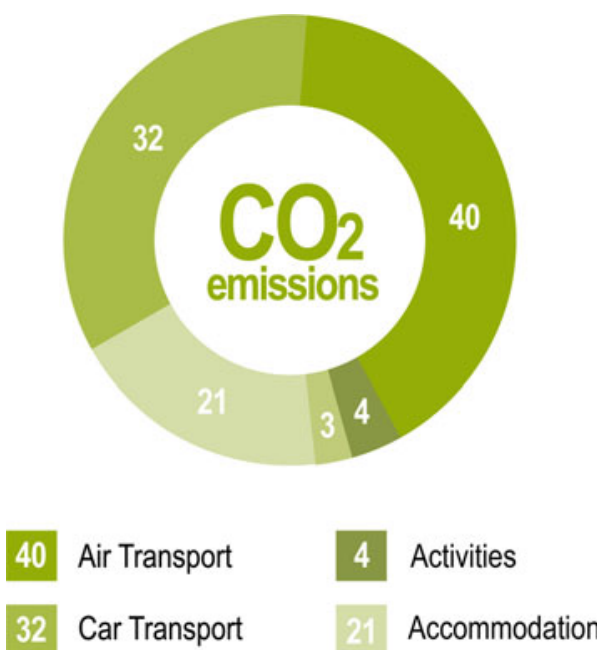

\section{Other Transport}

Fig. 17.3 Percentage contribution of tourism sub-sectors to carbon dioxide emissions (UNWTO/UNEP 2008)

Nevertheless, more frequent extreme weather events over the past few years have raised awareness of the need for climate change adaptation and disaster reduction (d'Mello et al. 2009; Becken and Hughey 2013).

Tourism is, in parts, an energy-intensive industry and so itself contributes to climate change. According to UNWTO/UNEP (2008), global tourism accounts for $5 \%$ of global carbon dioxide emissions (Fig. 17.3). A business-as-usual scenario projects emissions from global tourism to grow by $161 \%$ between 2005 and 2035. Emissions from air transport and accommodation are expected to triple. Two alternative emission scenarios show that mitigation solutions using technology only are hard to achieve. Even combined with behavioural changes, no significant reductions in carbon emissions can be gained in 2035 compared to 2005 (IPCC 2014c). In a recent article on tourism's global environmental impact, Gössling and Peeters (2015) predict that tourism-related energy use, emissions, and water, land and food requirements will double within the next 24 45 years. The growth factor for the different components varies from 1.92 (fresh water) to 2.89 (land use) for 2050 . An alternative development is possible, but would require a tremendous effort by politics, industry and tourists. But as the demand for tourism is expected to increase (IPCC 2014c), mitigation options are necessary. More research is needed, especially in the transport sector (such as on switching from kerosene to biofuels) and the building sector (such as on retrofitting or energy-efficient new builds) (IPCC 2014c).

A key question is the extent to which tourists will change their travel plans to reduce their impact on global climate. Their apparent unwillingness to adapt their travel behaviour means that the greatest responsibility for mitigation remains with politicians, the tourism industry and tourism supply. According to Kreilkamp (2011), it is a matter of innovativeness: Adaption as well as mitigation actions can be used by companies that aim to differentiate themselves from competitors through innovative approaches and use such actions for effective public relations. Gössling et al. (2013) showed how climate policy may influence travel costs and tourism patterns. Countries with strong climate change policy frameworks (carbon taxes, emissions trading schemes, etc.) also show more interest in tourism-specific policies to address climate change (Becken and Hay 2012). No country has yet adopted a low-carbon tourism strategy (OECD/UNEP 2011) and academic research on tourism policy dealing with climate change is still rare (Becken 2013).

\subsection{Conclusions and Future Research}

Despite the many papers published up to today, an analysis of the content of four leading tourism journals showed that publications on climate change represented only $1.7 \%$ of all papers published between 2000 and 2009. It demonstrates that $66 \%$ of the 128 papers found were classified as studies of the potential impacts of climate change on destinations or changing visitation patterns, with $40 \%$ on winter ski tourism and less than $10 \%$ on small islands or coastal areas (Scott 2011). For a more detailed analysis of tourism knowledge with respect to climate change adaptation, mitigation and impacts see Hall (2012).

Gössling et al. (2012) summarised in their paper review of the complexity of demand responses and consumer behaviour influenced by climate change that some knowledge gaps remain. It is still difficult to understand the impacts of extreme weather and environmental events on tourist behaviour and this should be considered over both the short and the longer term. There is an assumption that rising temperatures will have positive effects for northern European tourist destinations. However, this does not consider the impact of negative environmental changes in the region or that tourists will still want to travel to climatically disadvantaged regions, since climate change is not the only factor affecting the attractiveness of travel destinations.

Destinations can seek to deal with climate change through adaptation measures and thereby lessen its potential impacts. Further research is needed on the relationship between the impacts of climate change and specific tourist behaviours, activities, or tourism flows to coastal destinations (Moreno and Amelung 2009). Also, as Scott et al. (2012b) pointed out, very few studies address the consequences of mitigation policy in tourism.

Despite some negative impacts, the direct consequences of climate change are expected to be mostly positive for the 
tourist industry in the North Sea region if supply can keep up with demand. The seasonal distribution of demand will improve substantially in summer, and the region will be able to compete better with other major destinations such as the Mediterranean Sea region due to the warmer, dryer summers expected in the future. As the season lengthens, there will be more days suitable for outdoor recreation. Overall, climate in the North Sea region for tourism will improve. However, other conditions, such as beach width, landscape, and water quality will be affected negatively.

Although the tourism industry has little influence on the behaviour of tourists (IPCC 2014c), it can still take action on tourism supply. Some researchers see a need for drastic changes in the forms of tourism and the uses of leisure time as well as in destinations (Ceron and Dubois 2005; UNWTO/UNEP 2008; Gössling et al. 2010; Dubois et al. 2011; Peeters and Landré 2012).

Further studies in the North Sea region are essential to better understand the role of climate change impacts on the attractiveness of tourist destinations; on a changing Tourism Climate Index on tourism there, on changes in tourism demand and on possible shifts in travelling. As catastrophic events show, such as terrorism or natural disasters, the tourism industry is resilient. Nevertheless, actors in the tourism industry along the North Sea coast need to minimise risks while seeking to take advantage of new opportunities. Multidisciplinary research is needed that considers tourism trends, including climate change, together with social, ecological, economic, technological and cultural developments. More research is needed on how the challenges brought by climate change could be addressed in a proactive and sustainable manner.

Open Access This chapter is distributed under the terms of the Creative Commons Attribution 4.0 International License (http:// creativecommons.org/licenses/by/4.0/), which permits use, duplication, adaptation, distribution and reproduction in any medium or format, as long as you give appropriate credit to the original author(s) and the source, provide a link to the Creative Commons license and indicate if changes were made.

The images or other third party material in this chapter are included in the work's Creative Commons license, unless indicated otherwise in the credit line; if such material is not included in the work's Creative Commons license and the respective action is not permitted by statutory regulation, users will need to obtain permission from the license holder to duplicate, adapt or reproduce the material.

\section{References}

Agnew MD, Palutikof JP (2000) Impacts of climate on the demand for tourism. In: Falchi MA, Zorini AO (eds) ECAC 2000. Tools for the Environment and Man of the year 2000. Proceedings of the Third European Conference on Applied Climatology, Pisa, Italy, October 2000
Amelung B, Moreno A (2012) Costing the impact of climate change on tourism in Europe: results of the PESETA project. Climatic Change 112:83-100

Amelung B, Viner D (2006) Mediterranean tourism: exploring the future with the tourism climate index. J Sustain Tour 14:349-366

Amelung B, Viner D (2007) The vulnerability to climate change of the Mediterranean as a tourist destination. In: Amelung B, Blazejczyk K, Matzarakis A (eds) Climate Change and Tourism Assessment and Coping Strategies

Amelung B, Nicholls S, Viner D (2007) Implications of global climate change for tourism flows and seasonality. J Travel Res 45:284-296

Becken S (2010) The Importance of Climate and Weather for Tourism: Literature Review. Lincol University, Research Archive. http://hdl. handle.net/10182/2920

Becken S (2013) A review of tourism and climate change as an evolving knowledge domain. Tourism Manage Persp 6:53-62

Becken S, Hay J (2012) Climate Change and Tourism: From Policy to Practice. Routledge

Becken S, Hughey K (2013) Tourism and natural disaster risk reduction Opportunities for integration. Tourism Manage 36:77-85

Becken S, Hay J, Espiner S (2011) The risk of climate change for tourism in the Maldives. In: Buter R, Carlsen J (eds) Island Tourism Development: Journeys Towards Sustainability. Cabi

Bicknell S, McManus P (2006) The canary in the coalmine: Australian ski resorts and their response to climate change. Geogr Res 44:386400

Bigano A, Hamilton JM, Tol RSJ (2006a) The impact of climate on holiday destination choice. Climatic Change 76:175-180

Bigano A, Hamilton JM, Maddison DJ, Tol RSJ (2006b) Predicting tourism flows under climate change - an editorial comment on Gössling and Hall (2006). Climatic Change 79:175-180

Bigano A, Bosello F, Roson R, Tol R (2008) Economy-wide impacts of climate change: a joint analysis for sea level rise and tourism. Mitig Adapt Strat Glob Change 13:765-791

Braun OL, Lohmann M, Maksimovic O, Meyer M, Merkovic A, Messerschmidt E, Riedel A, Turner M (1999) Potential impact of climate change effects on preferences for tourism destinations. A psychological pilot study. Climate Res 11:247-254

Bujosa A, Rosselló J (2012) Climate change and summer mass tourism: the case of Spanish domestic tourism. Climatic Change 117:363-375

Buzinde C, Manuel-Navarrete D, Morais D (2010) Tourists perceptions in a climate of change: eroding destinations. Ann Tourism Res 37:333-354

Ceron JP, Dubois G (2005) The potential impacts of climate change on French tourism. Curr Iss Tourism 8:125-139

Ciscar JC, Iglesias A, Feyen L, Szabó L, Van Regemorter D, Amelung B, Nicholls R, Watkiss P, Christensen OB, Dankers R, Garrote L, Goodess CM, Hunt Al, Moreno A, Richards J, Soria A (2011) Physical and economic consequences of climate change in Europe. Proc Natl Acad Sci U S Am 108:2678-2683

Coombers EG, Jones AP, Sutherland WJ (2008) The biodiversity implications of changes in coastal tourism due to climate change. Environ Conserv 35:319-330

Coombers EG, Jones AP, Sutherland WJ (2009) The implications of climate change on coastal visitor numbers: a regional analysis. J Coast Res 25:981-990

Crouch GI (1995) A meta-analysis of tourism demand. Ann Tourism Res 22:103-118

de Freitas CR (2003) Tourism climatology: evaluating environmental information for decision making and business planning in the recreation and tourism sector. Int J Biomet 48:45-54

de Freitas CR, Scott D, McBoyle G (2008) A second generation climate index for tourism (CIT): specification and verification. Int J Biomet 52:399-407 
Denstadli JM, Jacobsen JKS, Lohmann M (2011) Tourist perceptions of summer weather in Scandinavia. Ann Tourism Res 38:920-940

d'Mello C, McKeown J, Minninger S (2009) Disaster Prevention in Tourism: Perspectives on Climate Justice. Ecumenical coalition on tourism. Chiang Mai, Wanida Press

Dubois G, Ceron JP, Peeters P, Gössling S (2011) The future tourism mobility of the world population: Emission growth versus climate policy. Transport Res A 45:1031-1042

Endler C, Matzarakis A (2010) Schlussbericht zum Teilvorhaben "Klima- und Wetteranalyse". In: Mayer H, Matzarakis A (eds) Ber Met Inst Albert-Ludwigs-Univ Freiburg 22

Giannakopoulos C, Le Sager P, Bindi M, Moriondo M, Kostopoulou E, Goodess CM (2009) Climate changes and associated impacts in the Mediterranean resulting from a $2^{\circ} \mathrm{C}$ global warming. Glob Plan Change 68:209-224

Giupponi C, Shechter M (eds) (2003) Climate Change in the Mediterranean: Socio-economic Perspectives of Impacts, Vulnerability and Adaptation. Edward Elgar

Gössling S, Hall CM (2006) Uncertainties in predicting tourist flows under scenarios of climate change. Climatic Change 79:163-173

Gössling S, Peeters P (2015) Assessing tourism's global environmental impact 1900-2050. J Sustain Tour 23:639-659

Gössling S, Hall M, Peeters P, Scott D (2010) The future of tourism: Can tourism growth and climate policy be reconciled? A mitigation perspective. Tourism Recreation Res 35:119-130

Gössling S, Scott D, Hall CM, Ceron JP, Dubois G (2012) Consumer behaviour and demand response of tourists to climate change. Ann Tourism Res 39:36-58

Gössling S, Scott D, Hall MC (2013) Challenges of tourism in a low-carbon economy. WIREs Climate Change 4:525-538

Hall CM (2005) Tourism: Rethinking the Social Science of Mobility. Pearson

Hall CM (2008) Santa Claus, place branding and competition. Fennia 186:59-67

Hall CM (2010) Climate change and its impacts on tourism: Regional assessments, knowledge, gaps and issues. In: Jones A, Phillips M (eds) Disappearing Destinations: Climate Change and the Future Challenges for Coastal Tourism. Cabi

Hall CM (2012) Tourism and climate change: knowledge gap and issue. In: Singh TV (ed) Critical Debates in Tourism. Short Run Press

Hamilton JM (2005) Tourism, Climate Change and the Coastal Zone. Dissertation Univ Hamburg

Hamilton JM (2006) Coastal landscape and the hedonic price of accommodation. Ecol Econ 62:594-602

Hamilton JM, Tol RSJ (2007) The impact of climate change on tourism in Germany, the UK and Ireland: A simulation study. Reg Env Change 7:161-172

Hamilton JM, Maddison DJ, Tol RSJ (2005) Climate change and international tourism: a simulation study. Glob Env Change A $15: 253-266$

Harrison R, Kinnaird V, McBoyle G, Quinlan C, Wall G (1986) Climate change and downhill skiing in Ontario. Ont Geogr 28:51-68

Hein L (2007) The impact of climate change on tourism in Spain. CICERO Working Paper 2007:02

Hein L (2009) Potential impacts of climate change on tourism; a case study for Spain. Curr Opin Environ Sustain 1:170-178

Hill A (2009) Holiday deals abroad vanish in rush to flee the rain. The Observer, 9 August 2009

IPCC (2014a) Climate Change 2014: Impacts, Adaptation, and Vulnerability. Part A: Global and sectoral aspects. Working Group II Contribution to the Fifth Assessment Report of the Intergovernmental Panel on Climate Change. Field CB, Barros VR, Dokken DJ, Mach KJ, Mastrandrea MD, Bilir TE, Chatterjee M, Ebi KL, Estrada YO, Genova RC, Girma, Kissel ES, Levy AN, MacCracken S, Mastrandrea PR, White LL (eds). Cambridge University Press
IPCC (2014b) Climate Change 2014: Impacts, Adaptation, and Vulnerability. Part B: Regional Aspects. Contribution of Working Group II to the Fifth Assessment Report of the Intergovernmental Panel on Climate Change. Barros VR, Field CB, Dokken DJ, Mastrandrea MD, Mach KJ, Bilir TE, Chatterjee M, Ebi KL, Estrada YO, Genova RC, Girma B, Kissel ES, Levy AN, MacCracken S, Mastrandrea PR, White LL (eds). Cambridge University Press

IPCC (2014c) Climate Change 2014: Mitigation of Climate Change. Working Group III Contribution to the Fifth Assessment Report of the Intergovernmental Panel on Climate Change. Edenhofer O, Pichs-Madruga R, Sokona Y, Farahani E, Kadner S, Seyboth K, Adler A, Baum I, Brunner S, Eickemeier P, Kriemann B, Savolainen J, Schlömer S, von Stechow C, Zwickel T, Minx JC (eds). Cambridge University Press

Jones A, Phillips M (eds) (2011) Disappearing Destinations: Climate Change and the Future Challenges for Coastal Tourism. Cabi

Jorgensen F, Solvoll G (1996) Demand models for inclusive tour charter: the Norwegian case. Tourism Manage 17:17-24

Kreilkamp E (2011) Klimawandel und Tourismus - Herausforderungen für Destinationen. Z Tourismus 3:203-219

Lemelin H, Dawson J, Stewart EJ, Maher P, Lueck M (2010) Last chance tourism: the boom, doom, and gloom of visiting vanishing destinations. Curr Iss Tourism 13:477-493

Lise W, Tol RSJ (2002) Impact of climate on tourist demand. Climatic Change 55:429-449

Lohmann M (2002) Coastal resorts and climate change. In: Lockwood A, Medlik S (eds) Tourism and Hospitality in the 21st Century. Butterworth-Heinemann

Lohmann M (2003) Über die Rolle des Wetters bei Urlaubsreiseentscheidungen. In: Bieger $\mathrm{T}$, Laesser $\mathrm{C}$ (eds) Jahrbuch 2002/2003 der Schweizerischen Tourismuswirtschaft. St. Gallen

Lohmann M, Kaim E (1999) Weather and holiday preference - image, attitude and experience. Rev Tourisme 2:54-64

Maddison D (2001) In search of warmer climates? The impact of climate change on flows of British tourists. Climatic Change 49:193-208

Matzarakis A (2007) Entwicklung einer Bewertungsmethodik zur Integration von Wetter- und Klimabedingungen im Tourismus. Ber Met Inst Univ Freiburg 16

Mieczkowski Z (1985) The tourism climate index: A method of evaluating world climates for tourism. Can Geogr 29:220-233

Moreno A (2010) Mediterranean tourism and climate (change): a survey-based study. Tourism Planning Dev 7:253-265

Moreno A, Amelung B (2009) Climate change and tourist comfort on Europe's beaches in summer: a reassessment. Coast Manage 37:550-568

Moreno A, Becken S (2009) A climate change vulnerability assessment methodology for coastal tourism. J Sustain Tour 17:473-488

Morgan R, Gatell E, Junyent R, Micallef A, Özhan E, Williams A (2000) An improved user-beach climate index. J Coast Conserv 6:41-50

Moriondo M, Giannakopoulos C, Bindi M (2011) Climate change impact assessment: the role of climate extremes in crop yield simulation. Climatic Change 104:679-701

Nicholls S, Amelung B (2008) Climate change and tourism in northwestern Europe: Impacts and adaptation. Tourism Anal 13:21-31

Nicholls RJ, Hoozemans FMJ (1996) The Mediterranean: vulnerability to coastal implications of climate change. Sustainable development at the regional level. Med Ocean Coast Manage 31:105-132

Nicholls RJ, Klein RJT (2003) Climate Change and Coastal Management on Europe's Coast. EVA WP No. 3

Nilsson JH, Gössling S (2012) Tourist responses to extreme environmental events: The case of Baltic Sea algal blooms. Tourism Planning Dev 10:32-44 
OECD, United Nations Environment Program (UNEP) (2011) Climate Change and Tourism Policy in OECD Countries. Paris, Organization for Economic Co-operation and Development OECD

Peeters PM, Landré M (2012) The emerging global tourism geography? An environmental sustainability perspective. Sustainability 4:42-71

Perch-Nielsen SL (2010) The vulnerability of beach tourism to climate change - an index approach. Climatic Change 100:579-606

Perch-Nielsen SL, Amelung B, Knutti R (2010) Future climate resources for tourism in Europe based on the daily tourism climatic index. Climatic Change 103:363-381

Perry A (2005) The Mediterranean: how can the world's most popular and successful tourist destination adapt to a changing climate? In: Hall CM (ed) Tourism, Recreation and Climate Change. Channel View Publ

Perry A (2006) Will predicted climate change compromise the sustainability of Mediterranean tourism? J Sustain Tour 14:367-375

Phillips MR, Jones AL (2006) Erosion and tourism infrastructure in the coastal zone: problems, consequences and management. Tourism Manage 27:517-524

Pinnegar JK, Viner D, Hadley D, Sye S, Harris M, Berkhout F, Simpson M (2006) Alternative future scenarios for marine ecosystems. Tech Rep. CEFAS, Lowestoft

Regierungskommission Klimaschutz (2012) Empfehlung für eine niedersächsische Stratgegie zur Anpassung an die Folgen des Klimawandels. Niedersächsisches Ministerium für Umwelt, Energie und Klimaschutz, Hannover

Rosselló J, Aguiló E, Riera A (2005) Modelling tourism demand dynamics. J Travel Res 44:111-116

Rosselló-Nadal J, Riera-Font A, Cárdenas V (2011) The impact of weather variability on British outbound flows. Climatic Change 105:281-292

Rutty M, Scott D (2010). Will the Mediterranean become "too hot" for tourism? A reassessment. Tourism Planning Dev 7:267-281

Rutty M, Scott D (2013) Differential climate preferences of international beach tourists. Climate Res 57:259-269

Schleupner C (2008) Evaluation of coastal squeeze and its consequences for Caribbean island Martinique. Ocean Coast Manage $51: 383-390$

Scott D (2011) Why sustainable tourism must address climate change. J Sustain Tour 19:17-34

Scott D, Becken S (2010) Editorial introduction. Adapting to climate change and climate policy: progress, problems and potentials. J Sustain Tour 18:283-295

Scott D, Lemieux C (2010) Weather and climate information for tourism. Procedia Environ Sci 1:146-183
Scott D, McBoyle G (2001) Using a 'tourism climate index' to examine the implications of climate change for climate as a natural resource for tourism. In: Matzarakis A, de Freitas CR (eds) Proceedings of the first international workshop on climate, tourism and recreation. International Society of Biometeorology, Commission on Climate, Tourism and Recreation, Halkidi, Greece

Scott D, McBoyle G, Schwartzentruber M (2004) Climate change and the distribution of climatic resources for tourism in North America. Climate Res 27:105-117

Scott D, Gössling S, de Freitas C (2008) Preferred climate for tourism: Case studies from Canada, New Zealand and Sweden. Climate Res 38:61-73

Scott D, Gössling S, Hall CM (2012a) International tourism and climate change. WIREs Climate Change 3:213-232

Scott D, Hall CM, Gössling S (2012b) Tourism and Climate Change. Impacts, Adaptation and Mitigation. Routledge

Scott D, Sim R, Simpson M (2012c) Sea level rise impacts on coastal resorts in the Caribbean. J Sustain Tour 20:883-898

Smith K (1993) The influence of weather and climate on recreation and tourism. Weather 48:398-404

Turton S, Dickson T, Hadwen W, Jorgensen B, Pham T, Simmons D, Tremblay P, Wilson R (2010) Developing an approach for tourism climate change assessment: evidence from four contrasting Australian case studies. J Sustain Tour 18:429-448

UNWTO (2009) From Davos to Copenhagen and Beyond: Advancing tourism's response to climate change. United Nations World Tourism Organization (UNWTO) background paper.

UNWTO/UNEP (2008) Climate Change and Tourism: Responding to global challenges. UN World Tourism Organization (UNWTO), United Nations Environment Programme (UNEP)

von Bergner NM, Lohmann M (2014) Future Challenges for Global Tourism: A Delphi Survey. J Travel R 53(4):420-432

Wall G, Harrison R, Kinnaird V, McBoyle G, Quinlan C (1986) The implications of climate change for camping in Ontario. Recreation Research Review 13:50-60

Wietze L, Tol RSJ (2002) Impact of climate on tourist demand. Climatic Change 55:429-449

Willms J (2007) Climate change = tourism change? The likely impacts of climate change on tourism in Germany's North Sea coast destinations. In: Matzarakis A, de Freitas CR, Scott D (eds) Developments in Tourism Climatology. Commission on Climate, Tourism and Recreation

Witt SF, Witt CA (1995) Forecasting tourism demand: A review of empirical research. Int J Forecasting 11:447-475 